\title{
Flight Observations for the Inventory of Glaciers in the Nepal Himalayas*
}

\author{
K. Higuchi**, T. Iozawa** and H. Higuchi***
}

\begin{abstract}
Air flights for photographing glaciers in Nepal Himalayas were carried out eight times during the period from 1970 to 1975 . The oblique aerial photographs of glaciers in the Khumbu region taken by these flights will aid to be compared with the glacier inventory by Müller (1970) and the maps hitherto published, as a first step in the inventory study of glaciers in this region.
\end{abstract}

\section{Introduction}

Flight observations of glaciers are quite important in the inventory compilation of glaciers in the Nepal Himalayas, since there are many high mountains. However, it is not easy to take vertical photographs of glaciers, because of the difficulty of chartering an aircraft from which aerial photographs can be taken vertically from an altitude higher than the mountain ranges. Projects to take aerial photographs of the land surface is being planned in Nepal by His Majesty's Government of Nepal and the United Nations Developing Project for mapping and land use. Therefore, it will be possible in the future to take vertical photographs of glaciers as a part of these projects.

At the present stage, it is useful for the inventory of glaciers in the Nepal Himalayas to take oblique photographs from aircraft at an altitude of not much higher than the summit of the mountains, since the oblique photographs

Table 1. List of flights for photographing glaciers in the Nepal Himalayas (1970-1975)

\begin{tabular}{|c|c|c|c|c|c|}
\hline $\begin{array}{l}\text { Flight } \\
\text { No. }\end{array}$ & Date & Type of aircraft & Flight altitude & Photographs & Members \\
\hline 1 & 6 Oct. 1970 & $\begin{array}{r}\text { Hawker Siddeley } \\
748\end{array}$ & $6000-7000 \mathrm{~m}$ & & $\begin{array}{l}\text { Iozawa and } \\
\text { Sawada }\end{array}$ \\
\hline 2 & 21 Nov. 1970 & $\begin{array}{l}\text { Pilatus Turbo } \\
\text { Porter }\end{array}$ & " & $\begin{array}{l}360 \text { photos in colour } \\
400 \text { photos in black and }\end{array}$ & $\begin{array}{l}\text { Iozawa and } \\
\text { Kanou }\end{array}$ \\
\hline 3 & 1 Jan. 1972 & $\begin{array}{r}\text { Hawker Siddeley } \\
748\end{array}$ & "1 & $\begin{array}{c}370 \text { photos in colour } \\
2000 \text { photos in black and } \\
\text { white }\end{array}$ & $\begin{array}{l}\text { Iozawa and } \\
\text { AMKAS Group }\end{array}$ \\
\hline 4 & 5 Jan. 1972 & $\begin{array}{l}\text { De Havilland } \\
\text { Twin Otter }\end{array}$ & " & & $\begin{array}{l}\text { Ohmori and } \\
\text { Iozawa }\end{array}$ \\
\hline 5 & 6 Jan. 1972 & "I & "I & & "I \\
\hline 6 & 21 Dec. 1974 & $\begin{array}{c}\text { Pilatus Turbo } \\
\text { Porter }\end{array}$ & "I & & $\begin{array}{l}\text { Ohmori, Inoue } \\
\text { and Iozawa }\end{array}$ \\
\hline 7 & 23 Dec. 1974 & Boeing 727 & $9900 \mathrm{~m}$ & $\begin{array}{l}800 \text { photos in colour } \\
2000 \text { photos in black and }\end{array}$ & $\begin{array}{l}\text { Higuchi, Iozawa } \\
\text { and } \\
\text { GEN members }\end{array}$ \\
\hline 8 & 30 Nov. 1975 & $\begin{array}{l}\text { Pilatus Turbo } \\
\text { Porter }\end{array}$ & $8000 \mathrm{~m}$ & $\begin{array}{l}300 \text { photos in colour } \\
400 \text { photos in black and } \\
\text { white }\end{array}$ & $\begin{array}{l}\text { Watanabe, } \\
\text { Fushimi, Ikegami } \\
\text { et. al. }\end{array}$ \\
\hline
\end{tabular}

* Glaciological Expedition to Nepal, Contribution No. 5

** Water Reseach Institute, Nagoya University, Nagoya 464

*** Faculty of Technology, Ehime University, Matsuyama 790 

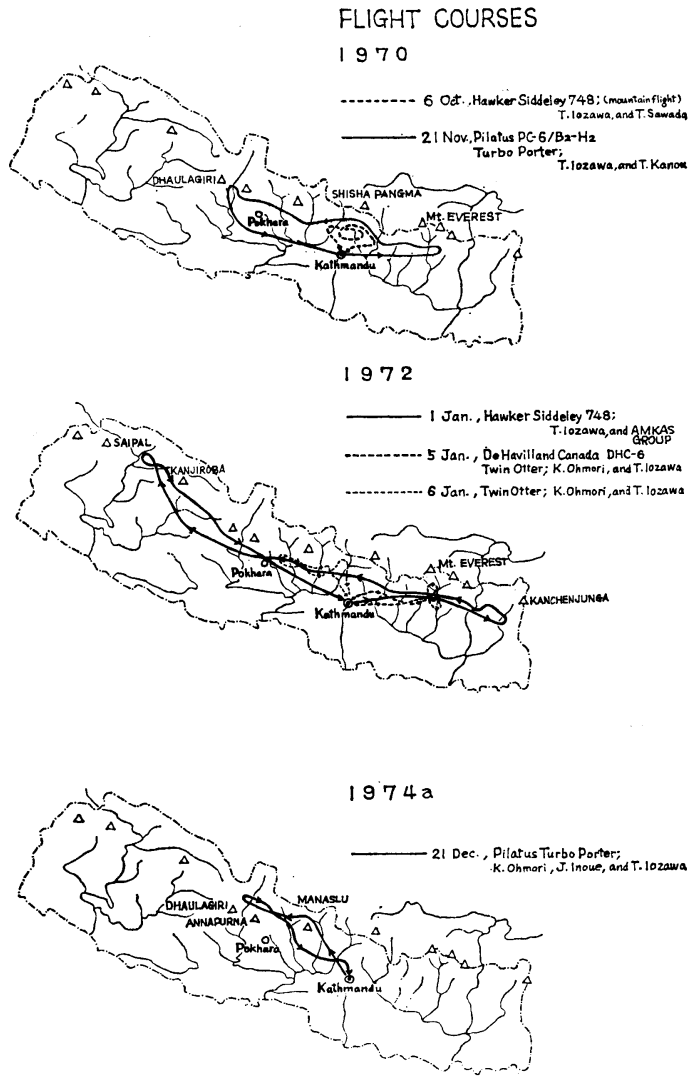

Fig. 1. Flight courses for phtographing glaciers in the Nepal Himalayas (1970-1974).

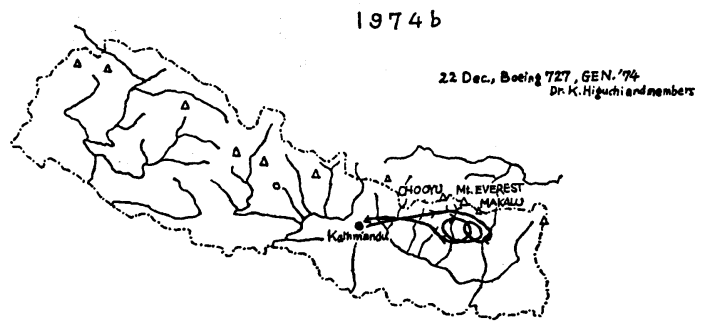

Fig. 1. (continued)

can give much informations over a wider area than vertical photographs. Therefore, flight observations of glaciers were carried out in the Nepal Himalayas by taking oblique photographs.

\section{Flight observations of glaciers}

During the period from 1970 to 1975, flights for photographing glaciers in the Nepal Himalayas were carried out eight times as summerized in Table 1. The flights in 1970 and 1972 were carried out mainly under guidance of Iozawa (1971). The flights in 1974 and 1975 were carried out as a part of the Glaciological Expedition to Nepal. The flight courses except for flight No. 8 are shown in Fig. 1. The area photographed by these flights is shown in Fig. 2.

\section{Inventory of glaciers in the Khumbu Region}

As seen in Fig. 1. many photographs of glaciers in the Khumbu region were taken by the flights

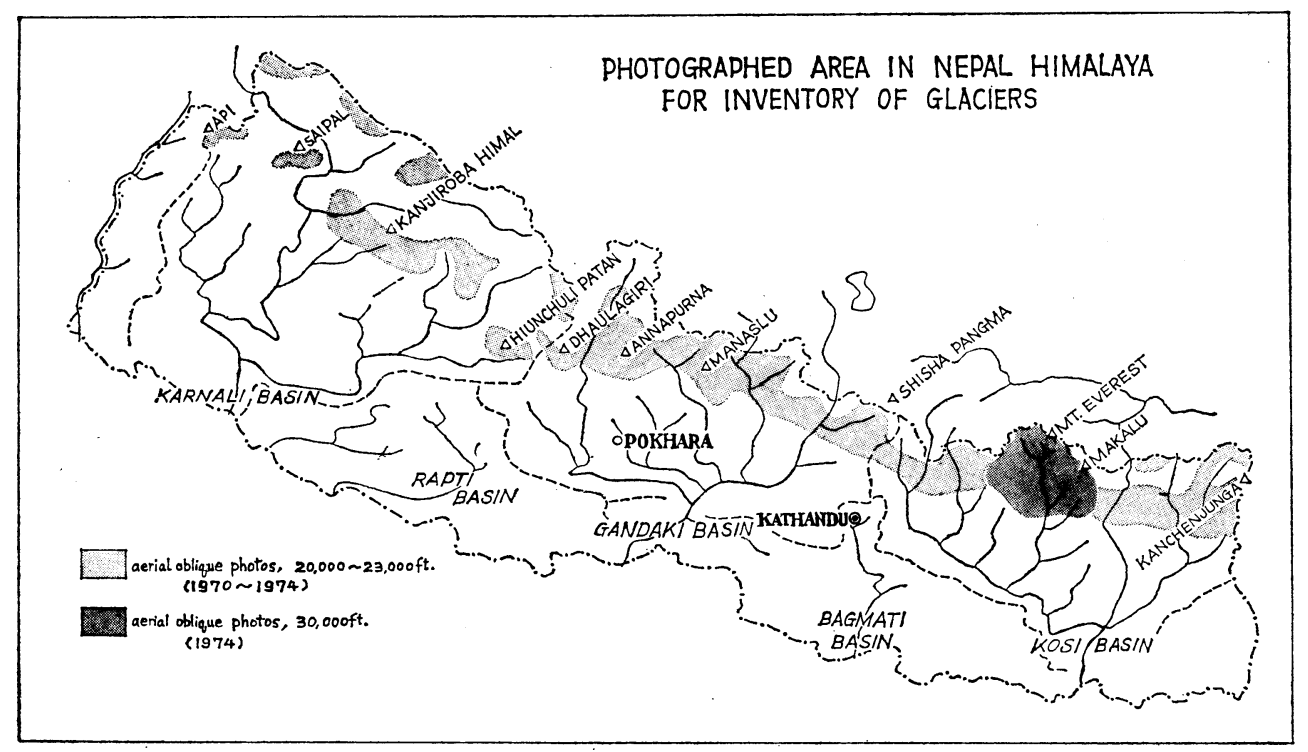

Fig. 2. Photographed area in Nepal Himalayas for inventory of glaciers. 

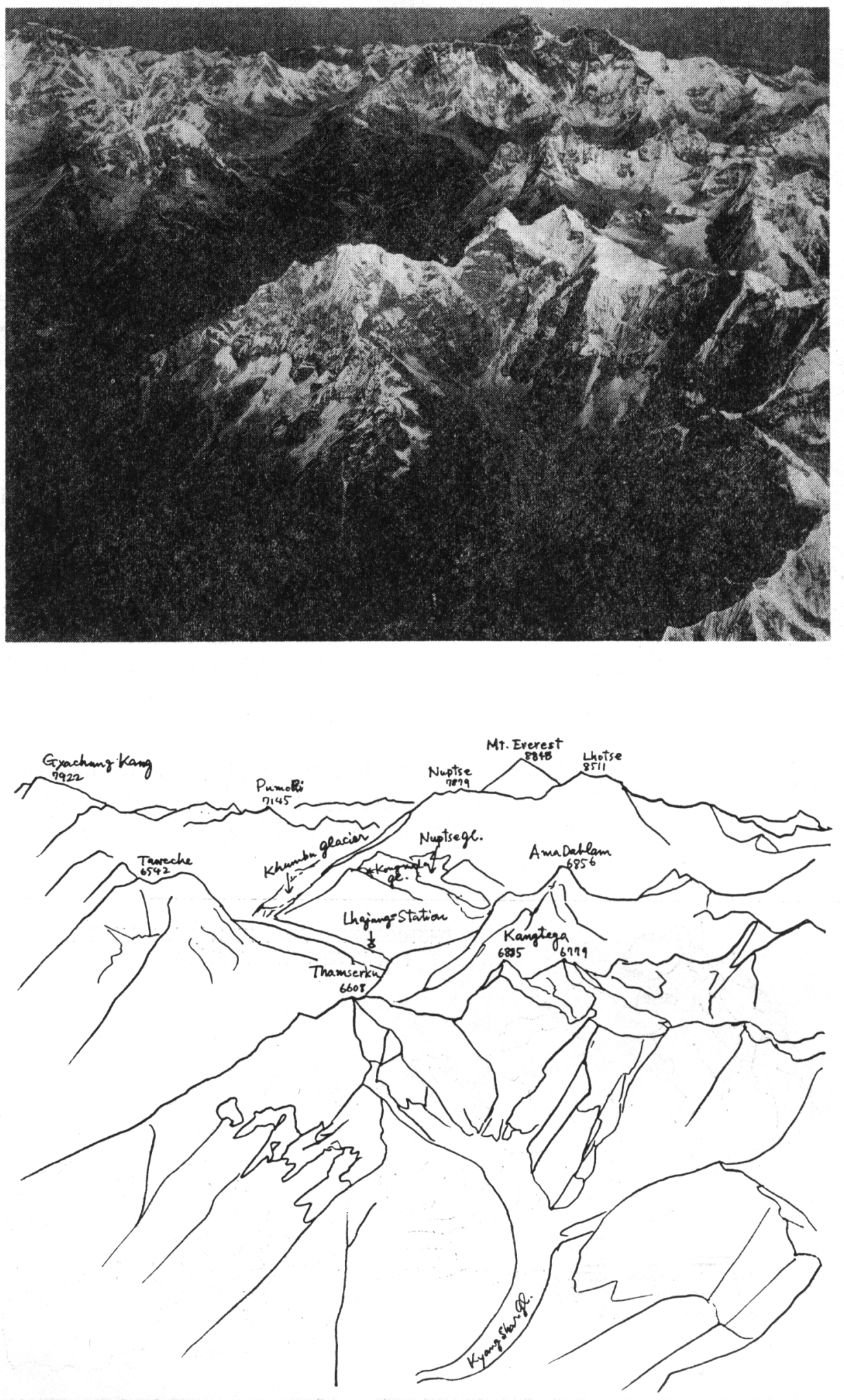

Fig. 3. Oblique photograph of the Mt. Everest region. 
Table 2. Maps used for the inventory of glaciers in the Khumbu region

1. Schneider (1957): Mahalangur Himal $(1: 25,000)$ contour interval $20 \mathrm{~m}$.

2. Schneider (1965): Khumbu Himal (1:50,000) contour interval $40 \mathrm{~m}$.

3. Royal Geographical Society (1961): The Mount Everest Region $(1: 100,000)$ contour interval $100 \mathrm{~m}$.

4. Research Scheme Napal Himalaya (1968): Rolwaling Himal (Gaurisankar) NEPAL (1:50,000) contour interval $40 \mathrm{~m}$.

5. Research Scheme Nepal Himalaya (1974): Shorong/Hinku $(1: 50,000)$ contour interval $40 \mathrm{~m}$.

in 1974 and 1975. Especially, since the flight on 23 December, 1974 was made by a Boeing 727 jet aircraft, the oblique photographs in this case covered a wider area from a higher altitude than the flights by other aircraft. An example is shown in Fig. 3.

Also, as seen in the pilot work by Müller (1970), the source materials for glacier inventory are rich in the Khumbu region than that of other region in Nepal Himalayas.

Therefore, the aerial photographs of the glaciers in the Khumbu region taken by these flights will be compared with the inventory by Müller and the maps in Table 2, as the first step in the inventory of glacier in this region. The results will be published in the future.

\section{References}

Müller, F., (1970): Inventory of glaciers in the Mount Everest region. "Perennial ice and snow masses", Technical papers in Hydrology 1, UNESCO/IASH, 47-59.

Iozawa, T., (1971): Nepal Himalayas no Hyôga Yosatsu (Preliminary study of glaciated land form in the Nepal Himalayas). Geographical Review of Japan, 44, 405-406. 